\title{
DOKTRIN KHILAFAH SEBAGAI ANCAMAN TERHADAP KONSTRUKSI NEGARA HUKUM INDONESIA
}

\author{
Abdul Wahid; Sunardi; Dwi Ari Kurniawati
}

\author{
Universitas Islam Malang \\ Jl. MT Haryono 193, Kota Malang \\ Email: visibos@gmail.com; dr.sunardis@yahoo.com; dwiarik@gmail.com
}

\begin{abstract}
Khilafah doctrine is one of the doctrines considered as a serious threat to the construction of the Unitary State of the Republic of Indonesia (NKRI), especially the constitutionality of Indonesia as a state of law that does not place a certain religion as the basis of state life. In this country of Indonesia, the implementation of social and state life is considered deviant, because it is not in accordance with sharia, whereas substantially, there are many legislative products in Indonesia, the legislative product is the character of the construction of the state law, which is essentially in line with the norms which applies in "fiqih" (Islamic law)
\end{abstract}

Keywords: State of Law, Khilafah Doctrine, Constitution, Substantiality

\begin{abstract}
ABSTRAK
Doktrin khilafah merupakan salah satu doktrin yang dinilai sebagai ancaman serius terhadap konstruksi Negara kesatuan Republik Indonesia (NKRI), khususnya konstitusionalitas Indonesia sebagai negara hukum yang memang tidak menempatkan agama tertentu sebagai dasar kehidupan bernegara. Di negara Indonesia ini, penyelenggaraan kehidupan bermasyarakat dan bernegara dinilai sudah menyimpang, karena tidak sesuai dengan syariah, padahal secara substansial, sudah banyak produk legislatif di Indonesia, yang produk legislatif ini menjadi karakter konstruksi negara hukum, yang secara esensialitas sudah sejalan dengan norma-norma yang berlaku dalam "fiqih" (hukum Islam)

Kata Kunci: Negara Hukum, Doktrin Khilafah, Konstitusi, Substansialitas
\end{abstract}

\section{PENDAHULUAN}

William James menyatakan, bahwa manusia dapat mengubah kehidupannya dengan mengubah sikap pikiran mereka. ${ }^{1}$ Pernyataan James ini menunjukkan, bahwa pikiran merupakan kekuatan yang dimiliki oleh manusia. Manusia bisa menunjukkan peran positip dalam kehidupannya sebagai individu maupun elemen bermasyarakat dan bernegara, salah satunya ditentukan oleh faktor penggunaan pikiran-pikirannya.

Dalam konstruksi pikiran manusia, terkumpul atau berkembang banyak dan beragam ideidenya, sehingga dari ranah ini, perannyamelalui

${ }^{1}$ Halimin Suhas, (2017), Mewujudkan Jalan Pencerahan, Jakarta: Hilman Media, Hlm. 1. 
sejumlah aktifitas ditentukan dan menentukan banyak aspek dalam kehidupan orang lain, sehingga tingkat keterpengaruhan seseorang atau sekelompok orang menjadi hal yang sulit dihindari ketika berhubungan dengan dirinya.

Dalam konstruksi pikiran itulah, diantaranya ada doktrin yang dipahami dan dikembangkan. Setiap orang atau sekelompok orang bisa mempelajari atau mempercayai doktrin. Soal dari mana doktrin itu berasal dan berkembang, manusia menjadi penentunya. Disinilah doktrin bisa berlanjut dipelajari atau dipercayainya. Ketika dipercaya dan apalagi terus dikembangkan, sementara doktrin ini menyesatkan atau berlawanan, maka seringkali yang terjadi di masyarakat adalah kekacauan, minimal atmosfir paradoksal dan kekacauan.

Doktrin khilafah merupakan salah satu doktrin yang dipahami dan diyakini sekelompok orang, yang di Indonesia ini menjadi doktrin yang mengancam atau membahayakan, khusunya terhadap konstruksi hukum Indonesia. Perbedaan yang bercorak tidak mengakui hkum positip atau menjadian keyakinan atau pemahamannya sebagai yang "paling benar", membuat problem tersendiri bagi pemberakuan hukum Indonesia sekarang dan masa mendatang.

${ }^{2}$ Ibid. Hlm.1

\section{PEMBAHASAN}

\section{Doktrin Khilafah}

Salah satu doktrin yang dikembangkan sekelompok orang adalah khilafah. Khilafah berasal dari kata "al-khalfu-khalafa-yakhlufu" yang berarti belakang lalu berkembang menjadi "khalfun, kholifah, Khilafah, khalaif, dan khulafa." Dalam konstruksi kata-kata ini terkandung makna pengganti generasi, pemimpin dan pewaris bumi. Kata "khalafa" dalam arti kepemimpinan terdapat dalam Al-Qur'an dengan makna generasi pengganti (QS Al-Araf: 69, QS Maryam: 59). Suksesi atau pergantian generasi dan kepemimpinan (QS Al An'am: 165, QS Yunus: 14 dan 73, QS Al-Fatir: 39). ${ }^{2}$

Syekh Abdul Majid Al-Khalidi dalam Qowaid Nidzam Al-hukum fii Al Islam mendefinisikan kata "khilafah" secara syar'i adalah sebagai kepemimpinan umum bagi kaum muslimin yang secara keseluruhan didunia untuk menegakkan hukum-hukum syara serta mengemban dakwah Islam keseluruh dunia. Adapun khilafah menurut Syekh Abdul Qodir Hasan Baraja adalah wadah bagi kehidupan bersama seluruh kaum muslimin dimuka bumi untuk melaksanakan ajaran Islam dengan seorang Imam/Kholifah/Amirul mukminin sebagai pemimpin.

Berkhilafah berarti kita melaksanakan kewajiban beruIil amri minkum. Allah SWT mewajibkan setiap orang beriman untuk taat 
kepada Alloh, Rasulullah, dan Ulil amri minkum. Hal ini sebagaimana firman-Nya dalam Q.S. 4:59.

Ibnu Khaldun berpendapat, bahwa kepemimpinan atau ke-khalifah-an harus mampu menggerakan umat untuk bertindak sesuai dengan ajaran Islam dan menyeimbangkan kewajiban di dunia dan akhirat. (Kewajiban di dunia) dapat harus seimbang (dengan kewajiban untuk akhirat), seperti yang diperintahkan oleh Nabi Muhammad, semua kepentingan dunia harus mempertimbangkan keuntungan untuk kepentingan akhirat. Singkatnya (kekahlifahan) pada kenyataannya menggantikan Nabi Muhammad, beserta sebagian tugasnya, untuk melindungi agama dan menjalankan kekuasaan politik di dunia ini. ${ }^{3}$

Perlu diketahui bahwa pasca Khilafah Turki Utsmani berakhir pada 3 Maret 1924, beberapa kalangan menilai peran Islam dalam pentas politik global selama lebih dari 13 abad juga berakhir. Keberadaan atau eksistensi realitas umat Islam mulai saat itu dinilai telah terpuruk, baik dalam bidang politik, ekonomi, militer, budaya, sains atau teknologi maupun yang lainnya.

Selain itu, "penjajahan modern" yang dilancarkan (negara-negara) Barat terhadap dunia Islam disinyalir kuat menjadi faktor terpenting yang membangkitkan eskalasi "kerinduan" beberapa kelompok umat Islam terhadap sistem Khilafah Islamiyah yang pernah mengantarkan kejayaan Islam di masa silam. Maka, sejak saat itulah term "khilafah" menjadi isu harakah (pergerakan) Islam dengan misi dan agenda politik membangun kembali Daulah Islamiyah Internasional. ${ }^{4}$

Dalam dinamika perjuangannya, ide khilafah internasional ini pertama kali diperankan oleh jamaah Ikhwanul Muslimin yang didirikan di Mesir pada tahun 1928, dan selanjutnyq banyak dimainkan oleh jamaah Hizbut Tahrir yang didirikan di Jerusalem Timur tahun 1952. Dan baru-baru ini juga digaungkan oleh Islamic State of Iraq and Sham (ISIS) di Irak dan Syiria.

Selain di Syria dan Irak, di Indonesia, benih ide khilafah sudah ada sejak awal kemerdekaan tahun 1945, baik yang bersifat konstitusional, seperti Majelis Konstituante, atau bersifat militer, seperti dalam kasus DI/TII, yang berusaha mendirikan negara Islam dan menolak Pancasila. Era reformasi tahun 1998 yang memberikan ruang kebebasan publik, menjadikan isu khilafah di Indonesia kian vulgar dan menemukan momentumnya. Pembicaraan-pembicaraan yang mewacanakan isu khilafah semakin intens dan terbuka dikampanyekan, baik lewat opini-opini pemikiran maupun gerakan nyata. Seperti

3 ,http://www.nu.or.id/post/read/55557/khilafah-dalam-pandangan-nu, akses 15 April 2018.

${ }^{4}$ Ibid. 
mewacanakan Islam sebagai solusi dan edeologi alternatif mengusahakan bentuk pemerintahan Negara Indonesia dari Negara kesatuan berformat republik menjadi khilafah, berikut konstituisi Negara sejak dari UndangUndang Dasar 1945 dan hukum positif diangkat dari syari'ah Islamiyah seutuhnya. ${ }^{5}$

Berdasarkan deskripsi tersebut, maka NU dalam Musyawarah Nasional Alim Ulama yang diadakan pada tanggal 1-2 nopember 2104 memutuskan beberapa poin penting sehubungan dengan khilafah yaitu:

1. Islam sebagai agama yang komprehensif (din syamil kamil) tidak mungkin melewatkan masalah negara dan pemerintahan dari agenda pembahasannya.

Kendati tidak dalam konsep utuh, namun dalam bentuk nilai-nilai dan prinsipprinsip dasar (mabadi asasiyyah). Islam telah memberikan panduan (guidance) yang cukup bagi umatnya.

2. Mengangkat pemimpin (nashb al-imam) wajib hukumnya, karena kehidupan manusia akan kacau (fawdla/chaos) tanpa adanya pemimpin. Hal ini diperkuat oleh pernyataan para ulama terkemuka, antara lain: a) Hujjat al-Islam Abu Hamid alGhazali dalam Ihya' 'Ulum al-Din yang menyebutkan, bahwa Agama dan kekuasaan negara adalah dua saudara kembar. Agama merupakan fondasi, sedangkan kekuasaan negara adalah pengawalnya. Sesuatu yang tidak memiliki fondasi, akan runtuh, sedangkan sesuatu yang tidak memiliki pengawal, akan tersia-siakan, b) Syaikh al-Islam Taqi al-Din Ibn Taimiyyah dalam as-Siyasah al-Syar'iyyah fi Ishlah alRa'i wa al-Ra'iyyah, bahwa sesungguhnya tugas mengatur dan mengelola urusan orang banyak (dalam sebuah pemerintahan dan negara) adalah termasuk kewajiban agama yang paling agung. Hal itu disebabkan oleh tidak mungkinnya agama dapat tegak dengan kokoh tanpa adanya dukungan Negara.

3. Islam tidak menentukan apalagi mewajibkan suatu bentuk negara dan sistem pemerintahan tertentu bagi para pemeluknya. Umat diberi kewenangan sendiri untuk mengatur dan merancang sistem pemerintahan sesuai dengan tuntutan perkembangan kemajuan zaman dan tempat. Namun yang terpenting suatu pemerintahan harus bisa melindungi dan menjamin warganya untuk mengamalkan dan menerapkan ajarankan agamanya dan menjadi tempat yang kondusif bagi kemakmuran, kesejahteraan dan keadilan.

4. Khilafah sebagai salah satu sistem pemerintahan adalah fakta sejarah yang pernah dipraktikkan oleh al-Khulafa' al-Rasyidun. Al-Khilafah al-rasyidah adalah model yang 
sangat sesuai dengan eranya; yakni ketika kehidupan manusia belum berada di bawah naungan negara-negara bangsa (nation states). Saat itu umat Islam sangat dimungkinkan untuk hidup dalam satu sistem khilafah. Pada saat umat manusia bernaung di bawah negara-negara bangsa (nation states) maka sistem khilafah bagi umat Islam sedunia kehilangan relevansinya. Bahkan membangkitkan kembali ide khilafah pada masa kita sekarang ini adalah sebuah utopia.

5. Negara Kesatuan Republik Indonesia (NKRI) adalah hasil perjanjian luhur kebangsaan di antara anak bangsa pendiri negara ini. NKRI dibentuk guna mewadahi segenap elemen bangsa yang sangat mejemuk dalam hal suku, bahasa, budaya dan agama. Sudah menjadi kewajiban semua elemen bangsa untuk mempertahankan dan memperkuat keutuhan NKRI. Oleh karena itu, setiap jalan dan upaya munculnya gerakan-gerakan yang mengancam keutuhan NKRI wajib ditangkal. Sebab akan menimbulkan mafsadah yang besar dan perpecahan umat.

6. Umat Islam tidak boleh terjebak dalam simbol-simbol dan formalitas nama yang tampaknya islami, tetapi wajib berkomitmen pada substansi segala sesuatu. Dalam adagium yang populer di kalangan para ulama dikatakan, bahwa yang menjadi pegangan pokok adalah substansi, bukan simbol atau penampakan lahiriah, atau "yang menjadi pegangan pokok adalah sesuatu yang diberi nama, bukan nama itu sendiri”. Dengan demikian, memperjuangkan tagaknya nilainilai substantif ajaran Islam dalam sebuah negara, apapun nama negara itu, Islam atau bukan, jauh lebih penting daripada memperjuangkan tegaknya negara-simbol negara Islam. ${ }^{6}$

Kalau memahami rumusan yang dipaparkan NU itu jelas, bahwa kehidupan bernegara, termasuk dalam menjalankan norma-norma yuridis, bukan aspek tesktualitas atau formalitas yang menjadi pijakan utamanya, tetapi substansialitasnya. Kepentingan universalitas dan multikultualisme yang memang menjadi karakter kehidupan bernegara hukum yang inklusif merupakan hal utama (istimewa) dibandingkanmemenuhi kepentingan tekstualitasnya.

\section{Konstruksi Negara Hukum Indonesia}

Ide negara hukum, selain terkait dengan konsep 'rechtsstaat' dan 'the rule of law', juga berkaitan dengan konsep 'nomocracy' yang berasal dari perkataan 'nomos' dan 'cratos'. Perkataan nomokrasi itu dapat dibandingkan dengan 'demos' dan 'cratos' atau 'kratien' dalam 
demokrasi. 'Nomos' berarti norma, sedangkan 'cratos' adalah kekuasaan. Adapun yang dibayangkan sebagai faktor penentu dalam penyelenggaraan kekuasaan adalah norma atau hukum. Karena itu, istilah nomokrasi itu berkaitan erat dengan ide kedaulatan hukum atau prinsip hukum sebagai kekuasaan tertinggi. Dalam istilah Inggris yang dikembangkan oleh A.V. Dicey, hal itu dapat dikaitkan dengan prinsip "rule of law" yang berkembang di Amerika Serikat menjadi jargon "the rule of law, and not of man". Dalam ranah ini, yang sesungguhnya dianggap sebagai pemimpin adalah hukum itu sendiri, bukan orang. Dalam buku Plato berjudul "Nomoi" yang kemudian diterjemahkan ke dalam bahasa Inggris dengan judul "The Laws", jelas tergambar atau terdeskripsikan bagaimana ide nomokrasi itu sesungguhnya telah sejak lama dikembangkan dari zaman Yunani Kuno. ${ }^{8}$.

Pendapat lain menyebutkan, bahwa secara moral politik setidaknya ada empat alasan utama orang menuntut agar negara diselenggarakan

(dijalankan/diimplementasikan) berdasarkan atas hukum yaitu: (1) kepastian hukum, tuntutan perlakuan yang sama, (3) legitimasi demokrasi, dan (4) tuntutan akal budi. ${ }^{9}$. tuntutan pada akal budi ini menunjuk pada masalah etika, sehingga dalam ranah inilah, para pilar negara diingatkan kalau hukum negara membutuhkan landasan etika.

Negara hukum tidak bisa dilepaskan dari pengertian negara demokrasi. Hukum yang adil hanya ada dan bisa ditegakkan di negara yang demokratis. Dalam negara yang demokrasi, hukum diangkat, dan merupakan respon dari aspirasi rakyat. Oleh sebab itu hukum dari rakyat oleh rakyat dan untuk rakyat. ${ }^{10}$

Kalau mempelajari sejarah lain disebutkan, bahwa konsep "rule of law" sebagai lanjutan gagasan "negara hukum" dahulu, sebenarnya sudah dimulai oleh Kant, Stahl, Dicey, telah dibahas dalam berbagai pertemuan. Mulai dari Athena tahun 1955, Chicago 1957, Warsawa 1958, New Delhi 1959, Lagos 1961, Rio de Janero 1962.

Istilah "rechtsstaat" (negara hukum) adalah suatu istilah muncul abad ke-19. Lebih muda dari dari istilah-istilah ketatanegaraan lainnya seperti: demokrasi, konstitusi, kedaulatan, dan lain

\footnotetext{
${ }^{7}$ Lihat Plato: The Laws, Penguin Classics, edisi tahun 1986. Diterjemahkan dan diberi kata pengantar oleh Trevor J. Saunders, dalam Ahmad Shihab, Belajar Menghormati Profesi, LPKEI, Surabaya, 2011, Hlm. 15.

${ }^{8}$ Jimly Asshiddiqie, Cita Negara Hukum Indonesia Kontemporer, http://www.economic-law.net /jurnal/citanegarahukumindonesia.doc, akses 11 Januari 2017.

${ }^{9}$ Franz Magnis Suseno, (1994), Etika Politik; Prinsip-prinsip Moral Dasar Kenegaraan Modern, Jakarta: Gramedia Pustaka Utama, Hlm. 295.

${ }^{10}$ Purnadi Purbacaraka \& M. Chaidir Ali, (1986), Disiplin Hukum, Alumni, Bandung, Hlm. 18-24.
} 
sebagainya. Menurut Soediman Kartohadiprodjo, istilah "rechtsstaat" pertama kali digunakan oleh Rudolf ven Gueist seorang guru besar Berlin. Tetapi konsep negara hukum itu sendiri sudah dicetuskan sejak abad ke-17, bersama-sama dengan timbulnya perlawanan terhadap sistem pemerintahan (kekuasaan) yang absolut, otoriter, bahkan sewenangwenang. Secara teoritikal konsep negara hukum lahir sebagai reaksi terhadap konsep kedaulatan negara tradisional yang di gagas oleh: Augustinus, Thomas Aquinas (teori kedaulatan tuhan), Machiavelli, Paul Laband, Georg Jellinek (teori negara kekuasaan), Jean Bodin (teori kedaulatan raja), Thomas Hobbes (teori konstruk, Homo homini lupus), Rouseau, Montesquieu, John Lockc (teori kedaulatan rakyat), Hugo de Groot, Krabbe, Leon Duguit (teori kedaulatan hukum atau supremacy of law). ${ }^{11}$

Joeniarto $^{12}$ menyatakan bahwa negara hukum ("asas the rule of law") berarti dalam penyelenggaraan negara segala tindakan penguasa dan masyarakat negara harus berdasarkan atas hukum dan bukan berdasarkan atas kekuasaan belaka dengan maksud untuk membatasi kekuasaan penguasa dan melindungi kepentingan masyarakat yakni perlindungan terhadap hak asasi manusia dari tindakan yang sewenangwenang.

Menurut Hugo Krabbe (guru besar Universitas Leiden), yang dimaksud dengan "hukum" pada konsep negara hukum bukan semata-mata hukum formal yang diundangkan, tetapi hukum yang ada di masyarakat, dan hukum formal adalah benar apabila sesuai dengan hukum materiil yakni perasaan hukum yang hidup di masyarakat.

Menurut Friedrich Julius Stahl, negara hukum harus memenuhi (memiliki) empat unsur (elemen) yaitu: (1) terjaminnya Hak Asasi Manusia (HAM), (2) pembagian kekuasaan, (3) pemerintahan berdasarkan peraturan perundangundangan, dan (4) peradilan tata usaha negara. Ciri, unsur (elemen) negara hukum yang ditawarkan oleh AV. Dicey adalah: (1) supremacy of law, (2) equality before the law, dan (3) human rights. ${ }^{13}$

Unsur (elemen) yang harus ada bagi suatu negara hukum (Rule of Law) menurut International Commition of Jurist: (1) negara harus tunduk kepada hukum, (2) pemerintah harus menghormati hak-hak individu, dan (3) hakim harus dibimbing oleh rule of law. Menurut Friederich Julius Stahl negara hukum harus memenuhi unsur-unsur: (1) hak-hak dasar manusia, (2) pembagian kekuasaan,

\footnotetext{
${ }^{11}$ C.S.T. Kansil \& Christine S.T. Kansil, (2001) „Ilmu Negara, Jakarta: Pradnya Paramita, Hlm. 138-14.

${ }^{12}$ Chaidir Soleh, (2014), Menegakkan Supremasi Negara Hukum., Jember: Gugus Ilmu, Hlm. 4

${ }^{13}$ Ibid
} 
pemerintahan berdasarkan peraturans, dan (4) peradilan tata usaha negara. ${ }^{14}$

Berdasarkan beberapa pendapat tentang unsur (elemen) negara hukum maka dapat disimpulkan setidaknya ada delapan unsur (elemen) yang harus ada bagi suatu negara yang ingin dikualifikasikan sebagai negara hukum yaitu: (1) pengakuan dan perlindungan hak asasi manusia, (2) legalitas, (3) pembagian kekuasaan, (4) peradilan yang bebas dan tidak memihak, (5) kedaulatan rakyat, (6) demokrasi, (7) konstitusionil, (8) supremasi hukum.

Berdasarkan uraian tersebut dan tanpa maksud mengabaikan unsur (elemen) lain, bisa disimpulkan bahwa ciri khas negara hukum ialah adanya pengakuan dan perlindungan hak-hak asasi manusia dan supremasi hukum.

Negara hukum ialah suatu negara yang diatur dengan sebaik-baiknya berdasarkan undang-undang, sehingga segala kekuasaan dari alat-alat pemerintahan didasarkan atas hukum. Negara hukum adalah negara yang diperintah oleh hukum bukan oleh orang atau kelompok orang ( $a$ state that not governed by men, but by laws). Supomo mengartikan istilah "negara hukum" sebagai negara yang tunduk kepada hukum, peraturan perundangundangan yang berlaku bagi segala alat negara, badan negara, dan semua komponen negara.

Dalam ranah Indonesia adalah negara hukum secara formal pernah disebut (dirumuskan) dalam penjelasan ${ }^{15}$ Undang-Undang Dasar 1945 (UUD 1945) yang menyebutkan bahwa Indonesia adalah negara yang berdasarkan atas hukum (rechtsstaat) dan tidak berdasarkan atas kekuasaan belaka (machtsstaat), dianutnya sistem konstitusi, dan equality before the law sebagaimana ditegaskan dalam Pasal 27 UUD 1945, namun sekarang, setelah UUD 1945 diamandemen, istilah negara hukum sudah masuk dalam salah satu pasalnya. Demikian juga Mohammad Yamin dalam bukunya yang berjudul Proklamasi dan Konstitusi menyebutkan bahwa di negara kita (Indonesia) undang-undanglah atau hukumlah dan bukannya manusia yang harus memerintah. Undang-undang yang memerintah haruslah undang-undang yang adil bagi rakyat. ${ }^{16}$

Negara hukum (diistilahkan lagi pula rule of law) untuk Republik Indonesia antara lain harus mengacu pada Pembukaan UUD 1945 dan Pancasila yang menyebutkan bahwa negara melindungi segenap bangsa Indonesia dan seluruh tumpah darah Indonesia dan untuk memajukan kesejahteraan umum, mencerdaskan

\footnotetext{
${ }^{14} \mathrm{Ibid}$, Hlm. 5

${ }^{15}$ Sekarang istilah negara hukum diatur atau dirumuskan dalam pasal 1 UUD 1945, dan bukan lagi di bagian penjelasan.

${ }^{16}$ Sudargo Gautama, (1983), Pengertian Tentang Negara Hukum, Alumni, Bandung, Hlm. 21-22.
} 
kehidupan bangsa, dan ikut melaksanakan ketertiban dunia yang berdasarkan kemerdekaan perdamaian abadi dan keadilan sosial. Negara hukum Republik Indonesia harus menganut asas dan konsep Pancasila yang terkandung dalam Pembukaan UndangUndang Dasar 1945. (1) asas ketuhanan (mengamanatkan bahwa tidak boleh ada produk hukum nasional yang anti agama, anti ajaran agama), (2) asas kemanusiaan (mengamanatkan bahwa hukum nasional harus menjamin, melindungi hak asasi manusia), (3) asas kesatuan dan persatuan (mengamanatkan bahwa hukum Indonesia harus merupakan hukum nasional yang berlaku bagi seluruh bangsa Indonesia, berfungsi sebagai pemersatu bangsa), (4) asas demokrasi (mengamanatkan bahwa kekuasaan harus tunduk pada hukum yang adil, demokratis), (5) asas keadilan sosial (mengamanatkan bahwa semua warga negara mempunyai hak yang sama dan bahwa semua orang sama di hadapan hukum). ${ }^{17}$

Kepastian hukum sudah barang tentu hukum yang adil yang merupakan kebutuhan langsung masyarakat. Dengan hukum yang adil objektif dan pasti maka tidak ada pihak yang perlu takut diberlakukan sewenang- wenang. Hukum yang objektif dan adil sudah barang tentu menjamin bahwa pihak-pihak dalam negara diperlakukan sama. Legitimasi demokratis yang dimaksud ialah bahwa hukum yang berlaku dibuat oleh penguasa atau ejabat yang ditunjuk negara yang berdasarkan sistem demokrasi, sehingan dengan demikian hukum yang dibuat merupakan respon atas ide-ide yang ada atau berkembang di masyarakat karena yang membuat (penguasa) memang representasi dari masyarakat. ${ }^{18}$

Dalam deskripsi pemikiran ahli mengenai negara hukum tersebut menunjukkan, bahwa sebenarnya bangunan negara yang berbentuk negara hukum itu sangat kuat, karena yang menjadi penyangga bangunannya adalah kepentingan fundamental masyarakat atau negara. Mahfud MD menyebut, bahwa umat Islam Indonesia harus menerima sistem politik dan ketatanegaraan Indonesia yang berdasar Pancasila dan Undang-Undang Dasar (UUD) 1945. Sistem negara Pancasila yang berbasis pluralisme, Bhinneka Tunggal Ika, sudah kompatibel dengan realitas keberagaman dari bangsa Indonesia. ${ }^{19}$

Masuknya sejumlah hal sakral seperti pengakuan dan perlindungan hak asasi manusia, legalitas, pembagian kekuasaan, peradilan yang bebas dan tidak memihak, kedaulatan rakyat, demokrasi,

\footnotetext{
${ }^{17}$ Mochtar Kusumaatmadja, (1995), Pemantapan Cita Hukum dan Asas-Asas Hukum Nasional di Masa Kini dan Masa yang Akan Datang, Padjadjaran, Alumni, Bandung, Hlm. 8.

${ }^{18}$ Franz Magnis Suseno, Op.Cit., Hlm. :296

${ }^{19}$ https://nasional.kompas.com/read/2017/05/26/15370351/menolak.ide.khilafah, akses 15 April 2018.
} 
konstitusionil, dan supremasi hukum ke dalam konstruksi negara hukum membuat setiap negara yang menerapkannya akan membuatnya menjadi negara kuat.

\section{Doktrin Khilafah sebagai Ancaman}

Secara teoritis Indonesia merupakan negara hukum (sebagaimana digariskan konstitusi), yang ini berarti, bahwa dalam tataran ideal, Indonesia senantiasa menyandarkan kepada apa yang dimaksud dengan hukum dalam setiap kegiatan atau aktifisitasnya secara konstitusionalitas. Tegasnya, negara hanya boleh berbuat jika hukum memberikan otoritas atau kewenangan untuk melakukan itu, dan jika tidak, maka negara tidak boleh berbuat. Hukum menjadi payung dalam setiap langkah negara dan pemerintah merupakan kesadaran moral dan etika bernegara oleh segenap bangsa yang oleh hal itu menimbulkan kesadaran untuk terus membangun Indonesia memang sebagai negara hukum. ${ }^{20}$ Kesadaran demikian tidak selalu dimiliki setiap subyek sosial dan agama manusia Indonesia, karena ada saja sekelompok orang atau komunitas beragama yang menolak memahami eksistensi dan keberlakuan hukum negara, serta menjadikan hukum Islam sebagai sumber hukum mutlaknya.

Sebagai contoh adalah pemikiran Imam Najm al-Din al-Nasafi. Ia mendeskripsikan khlaifah dalam tulisannya, bahwa umat Islam tidak berdaya tanpa seorang pemimpin (imam, dalam hal ini khilafah) yang dapat memimpin mereka untuk menentukan keputusan, memelihara dan menjada daerah perbatasan, memperkuat angkatan bersenjata (untuk pertahanan negara), menerima zakat mereka (untuk kemudian dibagikan), menurukan tingkat perampokan dan pencurian, menjada ibadah di hari jumat (salat jumat) dan hari raya, menghilangkan perselisihan di antara sesama, menghakimi dengan adil, menikahkan wanita yang tidak memiliki wali. Sebuah keharusan bagi pemimpin untuk terbuka dan berbicara di depan orang yang dipimpinnya, tidak bersembunyi dan jauh dari rakyatnya. Ia sebaiknya berasal dari kaum Quraish dan bukan kaum lainnya, tetapi tidak harus dikhususkan untuk Bani Hasyim atau anak-anak Ali. Pemimpin bukanlah seseorang yang suci dari

\footnotetext{
${ }^{20}$ Di ranah hukum seringkali terjadi perkembangan yang kontroversial atau bertolak belakang atau masih belum sejalannya ide-ide besar dalam law in books dengan realitas hukum dalam penerapannya (law in action), di satu pihak produk materi hukum, pembinaan aparatur, sarana dan prasarana hukum menunjukkan peningkatan. Namun, di pihak lain tidak diimbangi dengan peningkatan integritas moral dan profesionalis me aparat hukum, kesadaran hukum, mutu pelayanan serta tidak adanya kepastian dan keadilan hukum sehingga mengakibatkan supremasi hukum belum dapat diwujudkan secara maksimal. Supremasi hukum masih seringkali dikalahkan oleh model-model perilaku masyarakat, khususnya aparatur penegak hukum, yang terjebak dalam perbuatan yang melanggar norma moral maupun hukum. Aparat penegak hukum tidak sedikit yang menyerah dikalahkan oleh pelaku kriminal dari kalangan elit atau berduit, lihat dalam Bambang Sasmita, Supremasi Kejahatan Elitis, Sumber Ilmu, Bandung, 2016, Hlm 5.
} 
dosa, dan bukan pula seorang yang paling jenius pada masanya, tetapi ia adalah seorang yang memiliki kemampuan administratif dan memerintah, mampu dan tegas dalam mengeluarkan keputusan dan mampu menjaga hukum-hukum Islam untuk melindungi orangorang yang terzalimi, serta mampu memimpin dengan arif dan demokratif.

Pemikiran Najm al-Din al-Nasafi itu jelas, bahwa meskipun ia menyebut kondisi general umat Islam yang sedang mengalami ketidakberdayaan atau "keterbelakangan", namun kondisi ini direlasikan dengan akar problematika yang dikaitkan dengan soal kekhalifahan dan penerapan hukum Islam.

Di luar pemikiran itu, perlu dipahami dari sisi kesejatian, bahwa produk hukum yang diidealisasikan sebagai payung di suatu masyarakat atau bangsa, belum tentu kuat menghadapi perubahan masyarakat lokal hingga global yang sangat dahsyat, khususnya masyarakat yang meyakini bahwa hanya pemikirannya yang "paling benar".

Quncy Wright mengingatkan, bahwa negara-negara di dunia yang terlibat atau terseret dengan globalisasi ekonomi dan perdagangan bebas ini, baik negara maju maupun negara berkembang, bahkan negara terbelakang sekalipun harus membuat standarisasi hukum dalam kegiatan tertentu (ekonomi). ${ }^{21}$ Besarnya pengaruh kekuatan di luar hukum seperti ini secara tidak langsung merupakan tantangan tersendiri bagi dunia hukum, khususnya para pengemban profesi hukum. Doktrin khilafah merupakan bagian dari ancaman serius bersifat globalitas yang disebar sejumlah orang yang tidak menghendaki berlakunya model negara hukum Indonesia yang tidak menggunakan ("nama") hukum Islam, apalagi salah satu jenis produk norma yuridisnya masih menggunakan produk hukum warisan kolonalis Belanda.

Selain itu, John Braitwaite and Peter Drahos menguatkan, bahwa proses integrasi ekonomi dari berbagai negara yang memerlukan harmonisasi hukum untuk meminimalisasi bentrokan hukum domestik dari negara-negara tersebut. Proses globalisasi hukum tersebut dapat terjadi melalui kontrak dan konvensi Internasional, kontrak privat dan institusi ekonomi baru. ${ }^{22}$ Dalam ranah seperti itu kelompok penganut paham khilafah terus berupaya memasukkan norma-norma yuridis yang diyakini kedalam proses integrasi supaya mendapatkan pengakuan, bahwa hukum (fiqih) juga Islam bisa mengisi

\footnotetext{
${ }^{21}$ Richard C. Breeden, “The Globalization of Law and Business In The 1990's, “Wake Forest Law Review, Vol. 28 No. 3 (1993), Hlm. 511-517.

${ }^{22}$ John Braitwaite and Peter Drahos, Global Business Regulation, Cambridge University Press, New York, 2000), Hlm. 24-25
} 
ranah globalisasi hukum, termasuk dalam mewujudkan harmonisasi yuridis.

Perlu dipahami oleh penganut paham khilafah, bahwa dalam kehidupan berbangsa yang pluralistik dan multikultralisme seperti Indonesia ini, salah satu teori hukum yang memiliki keterkaitan signifikan dengan etika kehidupan bermasyarakat dan berbangsa adalah "teori hukum sibernetika". Menurut Winner, teori ini mendeskripsikan, bahwa hukum itu merupakan pusat pengendalian komunikasi antar individu yang bertujuan untuk mewujudkan keadilan. Hukum itu diciptakan oleh pemegang kekuasaan atau para aparatnya, yang menurut premis yang mendahuluinya disebutnya sebagai "central organ". Perwujudan tujuan atau pengendalian itu dilakukan dengan cara mengendalikan perilaku setiap individu, penghindaran sengketa atau dengan menerapkan sanksisanksi hukum terhadap suatu sengketa. Dengan cara demikian, setiap individu diharapkan berperilaku sesuai dengan perintah, dan keadilan dapat terwujud karenanya. ${ }^{23}$

Teori itu menunjukkan tentang peran strategis pemegang kekuasaan yang memiliki kewenangan untuk membuat (melahirkan) hukum. Dari hukum yang berhasil disusun, diubah, diperbaharui atau diamandemen ini, lantas dikonsentrasikan tujuan mulianya untuk mengendalikan komunikasi antar individu dengan tujuan menegakkan keadilan. Melalui implementasi hukum dengan diikuti ketegasan sanksi-sanksinya, diharapkan perilaku setiap individu dapat dihindarkan dari sengketa, atau bagi anggota masyarakat yang terlibat konflik hukum atau sengketa, konflik atau pertikaian secara individual maupun kelompok, lantas dicarikan landasan pemecahannya dengan mengandalkan keberdaulatan hukum yang berlaku (sebagai hukum positip).

Pada tahapan cita-cita ideal itu, kalangan praktisi hukum yang juga menempatkan dirinya sebagai unsur penting dan strategis dalam organ kekuasaan dituntut berupaya secara optimal untuk mengindahkan, menyesuaikan dan mempertemukan antara tugas dan kewenangannya sesuai dengan perintah hukum dengan kaedah-kaedah etika dan agama yang berlaku di tengah masyarakat. Kaedah agama yang berlaku inilah yang secara langsung atau tidak langsung diantaranya yang diserap sebagai "fiqih", yang tidak harus dilaksanakan sebagai hukum negara.

Bekerjanya suatu norma hukum tidak lepas dari adanya konstruksi hukum. Sebagai bangunan sistematis, norma hukum memiliki beberapa hal penting sebagai penunjang yakni struktur, kategori dan konsep. Ketiga elemen ini menempati substansi mendasar dalam mana

\footnotetext{
${ }^{23}$ lili Rasyidi dan LB Wiyasa Putra, (1993), Hukum Sebagai Suatu Sistem, Bandung: Rosdakarya, Hlm. 58.
} 
hukum bekerja atau menunjukkan perannya yang menurut John Rawls menjadi " $a$ coercive order of public rules addressed to rational persons for the purpose of regulating their conduct and providing the framework for social cooperation". Jika mengakomodir pandangan John Rawls ini, bekerjanya hukum ini menurut Hari Chand disebabkan adanya beberapa rasionalitas praktis yang memenuhi tiga aspek masing-masing "value, right and moral worth, relates to social and institutions". ${ }^{24}$ Beberapa rasionalitas praktis inilah yang bisa menjadikan produk norma yuridis yang tidak dipahami oleh penganut paham khilafah. Dalam pandangan penganut paham ini, bahwa segala yang dilakukan oleh subyek hukum haruslah sesuai syariah, padahal apa yang diperbuat elemen bernegara ini, jika dicerna dalam ranah esensialitas norma, sejumla hal sudah membahakan kepentingan setiap pemeluk agama, termasuk pemeluk Islam.

Konsepsi tentang hukum selalu ada dan sekaligus merupakan sesuatu yang tidak dapat dihindari adanya dalam suatu sistem hukum yang berlaku dalam suatu negara. Sistem hukum yang berlaku di negara ini sudah jelas, meskipun tentu saja dalam pemikiran sejumlah orang atau komunitas beragama, dinilainya berlawanan dengan doktrin agama atau keyakinan komunitas penganut doktrin khilafah.

Bagaimana hukum yang dipahami, gambaran hukum yang bagaimana yang menjadi idée, serta hukum yang bagaimana yang timbul atas kebutuhan manusia merupakan wujud pemikiran mendalam dari manusia untuk memahami hukum itu sendiri, yang tentu saja pemahaman ini termasuk yang ditunjukkan oleh komunitas yang tidak sepaham dengan komunitas pengikut doktrin khilafah. Namun seharusnya mereka juga menyadari, bahwa kebutuhan manusia dalam memahami dan menerapkan hukum berelasi dengan banyak hajat (kepentingan) dan aspek lainnya. Pendapat Stammler yang menegaskan bahwa "the concept of law is the technical legal science which concerns with a legal system. It is the sum of laws which may be found in a legal system "25 memiliki keterkaitan dengan pemahaman dalam menghasilkan berbagai konsep keberlanjutannya.

\section{PENUTUP}

Di era global ini, berbagai doktrin berkembang dan "menyerang" kehidupan suatu Negara. Doktrin khilafah merupakan salah satu doktrin di dunia ini, yang oleh sebagian besar pemeluk Islam atau pemegang teguh ideologi Pancasila dinilai sebagai ancaman serius terhadap konstruksi Negara Kesatuan Republik Indonesia

\footnotetext{
${ }^{24}$ Hari Chand, (1994), Modern Jurisprudence, Kualalumpur: International Book Services, p.51.

${ }^{25}$ Ibid.
} 
(NKRI), khususnya konstitusionalitas Indonesia sebagai negara hukum yang memang tidak menempatkan agama tertentu sebagai dasar kehidupan bernegara (berpemerintahan).

Harus dipahami oleh semua pihak, bahwa di mata penganut doktrin khilafah, penyelenggaraan kehidupan bermasyarakat dan bernegara di negara Republik Indonesia ini, dinilainya sudah menyimpang, karena tidak sesuai dengan syariah, padahal secara substansial, sudah banyak produk legislatif di Indonesia, yang produk legislatif ini menjadi karakter konstruksi negara hukum, yang secara esensialitas sudah sejalan dengan norma-norma yang benar dalam perspektif doktrin Islam.

\section{DAFTAR PUSTAKA}

\section{Buku}

Ahmad Shihab, ,2011, Belajar Menghormati Profesi, Suraaya: LPKEI.

Bambang Sasmita, 2016, Supremasi Kejahatan Elitis, Bandung: Sumber Ilmu.

Chaidir Soleh, 2014, Menegakkan Supremasi Negara Hukum., Jember: Gugus Ilmu.

C.S.T. Kansil \& Christine S.T. Kansil, 2001, Ilmu Negara, Pradnya Paramita, Jakarta.

Franz Magnis Suseno, 1994, Etika Politik; Prinsip-prinsip Moral Dasar
Kenegaraan Modern, Jakarta: Gramedia Pustaka Utama.

Halimin Suhas, 2017, Mewujudkan Jalan Pencerahan, Jakarta: Hilman Media,

Hari Chand, 1994, Modern Jurisprudence, International Book Services: Kualalumpur,

John Braitwaite and Peter Drahos, 2000, Global

Business Regulation, New York: Cambridge University Press.

Lili Rasyidi dan LB Wiyasa Putra, 1993, Hukum Sebagai Suatu Sistem, Banudng: Rosdakarya.

Mochtar Kusumaatmadja, 1995, Pemantapan Cita Hukum dan Asas-Asas Hukum Nasional di Masa Kini dan Masa yang Akan Datang, Padjadjaran: Alumni..

Purnadi Purbacaraka \& M. Chaidir Ali, 1986, Disiplin Hukum, Alumni, Bandung Sudargo Gautama, 1983, Pengertian Tentang Negara Hukum, Bandung Alumni.

\section{Internet}

Http://www.nu.or.id/post/read/55557/khila fah-dalam-pandangan-nu, akses 15 April 2018.

https://nasional.kompas.com/read/2017/05/26/15 370351/menolak.ide.khilafah, akses 15 April 2018. 
220 Yurispruden Volume 1, Nomor 2, Juni 2018, Halaman 206-220

Jimly Asshiddiqie, Cita Negara Hukum Indonesia Kontemporer,http://www .economic-law.net /jurnal/citanegarahukumindonesia.doc, akses 11 Januari 2018.

Richard C. Breeden, "The Globalization of Law and Business In The 1990's, "Wake Forest Law Review, Vol. 28 No. 3 (1993), hal. 511-517. 